Spross Ch., van Riet R.P. Acute distal triceps tendon repair. Issue Rehabil. Orthop. Neurophysiol. Sport Promot. 2018;24:9-16. DOI: 10.19271/IRONS-000676-2018-24

\section{ACUTE DISTAL TRICEPS TENDON REPAIR}

Christian Spross ${ }^{1,2}$

Roger P. van Riet ${ }^{3,4}$

1Department of Orthopaedics and Traumatology, Kantonsspital St. Gallen, Switzerland ${ }^{2}$ Faculty of Medicine, University of Zurich, Zurich, Switzerland

${ }^{3}$ AZ Monica Hospital, Orthopaedic Centre Antwerp and Monica Orthopaedic Research (MoRe) Foundation, Antwerp, Belgium ${ }^{4}$ University of Antwerp, Wilrijkstraat 10, Edegem, Belgium

\section{SUMMARY}

Direct repair to the olecranon is the treatment of choice for acute distal triceps ruptures. Risk factors include chronic overuse, steroid (ab)use, previous surgery and systemic diseases. Unfortunately, triceps tendon ruptures are often missed acutely, resulting in a delayed diagnosis. Direct repair may no longer be possible in these patients and a tendon augmentation may be necessary. Diagnosis starts with a thorough clinical exam, followed by radiographic examinations. The patient may complain of some weakness and pain with swelling over the elbow and distal triceps tendon. During the clinical exam, a gapping of the central portion of the tendon insertion may be felt, both in a relaxed state and during contraction. Plain anteroposterior (AP) and lateral radiographs are the first line of imaging and may show a retracted flake of bone. This is pathognomonic for a triceps tendon avulsion from the olecranon. Ultrasound and MRI are more sensitive exams to confirm the diagnosis. The indication for surgery depends on the functional impairment and the specific demands of the patient. We have a low threshold for early surgical fixation of an acute rupture of the distal triceps tendon as it is easier to directly fix the tendon back to bone in acute rather than chronic
OSTRE USZKODZENIE PRZYCZEPU DYSTALNEGO MIĘŚNIA TRÓJGŁOWEGO

Christian Spross ${ }^{1,2}$

Roger P. van Riet ${ }^{3,4}$

1Department of Orthopaedics and Traumatology, Kantonsspital St. Gallen, Szwajcaria ${ }^{2}$ Faculty of Medicine, University of Zurich, Zurich, Szwajcaria

${ }^{3}$ AZ Monica Hospital, Orthopaedic Centre Antwerp and Monica Orthopaedic Research (MoRe) Foundation, Antwerp, Belgia ${ }^{4}$ University of Antwerp, Wilrijkstraat 10, Edegem, Belgia

\section{STRESZCZENIE}

Bezpośrednia reinsercja ścięgna mięśnia trójgłowego wyrostka łokciowego jest leczeniem z wyboru w przypadku ostrego uszkodzenia przyczepu dalszego mięśnia trójgłowego. Czynniki ryzyka uszkodzenia to przewlekłe nadużywanie, stosowanie kortykosteroidów, wcześniejsze zabiegi operacyjne i choroby ogólnoustrojowe. Niestety, uszkodzenia ścięgna mięśnia trójgłowego są często nierozpoznawalne, co skutkuje opóźnioną diagnozą. U tych pacjentów nie jest już możliwa bezpośrednia naprawa uszkodzenia i może być konieczna rekonstrukcja ścięgna. Postawienie rozpoznania opiera się na dokładnym badaniu klinicznym, a następnie wykonaniu badań radiograficznych. Pacjent może skarżyć się na osłabienie i ból oraz obrzęk stawu łokciowego i w okolicy dalszego przyczepu mięśnia trójgłowego. Podczas badania palpacyjnego wyczuwalny może być ubytek centralnej części ścięgna, zarówno w rozkurczu, jak i podczas skurczu mięśnia. Zdjęcia radiologiczne w projekcji przednio-tylnej (AP) i bocznej stanowią pierwszą linię obrazowania i mogą przedstawiać uszkodzenie ścięgna mięśnia trójgłowego z fragmentem kości. To patognomoniczne dla obrazu oderwania ścięgna mięśnia trójgłowego od wyrostka łokciowego. Badania ultrasonograficzne 
repairs. Our preferred technique is a primary hybrid fixation with drill holes and one central bone anchor. Depending on the stress on the repair, the triceps tendon is often protected with a brace to allow for progressive flexion. After three months, unrestricted use of the elbow is permitted. The outcome after triceps tendon repair is predictable and usually leads to excellent functional results. The complication rate is low and retears are rarely observed.

Keywords: triceps tendon, tendon rupture, repair, elbow

Date received: 12th January 2018

Date accepted: 14th February 2018

\section{Introduction}

Demographics and anatomy

Distal triceps tendon ruptures account for only $1 \%$ of all tendon ruptures (Anzel et al., 1959). The mean age of patients with a distal triceps rupture is about 45 years with a male to female ratio is $1: 7$. Sixty percent of triceps tendon tears involve the dominant side (van Riet et al., 2003). The tendon usually avulses from the olecranon bone, but musculotendinous and intramuscular ruptures have been described. Risk factors include previous surgery and chronic overuse. Specific athletic populations are at risk for triceps injuries like power lifters, bodybuilders, i rezonansu magnetycznego są najbardziej czułe dla potwierdzenia diagnozy. Wskazanie do operacji zależy od upośledzenia funkcji mięśnia trójgłowego i od specyficznych wymagań pacjenta. Grupa pacjentów z ostrym uszkodzeniem dalszego przyczepu ścięgna mięśnia trójgłowego jest mała, ponieważ w takich przypadkach łatwiej jest wykonać reinsercje ścięgna metodą otwartą niż w przypadkach przewlekłych. Naszą preferowaną metodą operacyjną jest pierwotna technika hybrydowa z użyciem szwów przezkostnych i jedną centralną kotwicą. W zależności od naprężenia rekonstruowanego ścięgna, ścięgno mięśnia trójgłowego jest często chronione za pomocą ortezy zegarowej umożliwiającej stopniowe zginanie w stawu łokciowego. Po trzech miesiącach pozwala się na pełen zakres ruchu. Wynik leczenia po artroskopowej naprawie ścięgna mięśnia trójgłowego jest przewidywalny i zwykle prowadzi do doskonałych wyników czynnościowych. Współczynnik powikłań jest niski i rzadko obserwuje się ponowne uszkodzenia.

Słowa kluczowe: ścięgno mięśnia trójgłowego, zerwanie ścięgna, operacja naprawcza, staw łokciowy

Data otrzymania: 12 stycznia 2018

Data zaakceptowania: 14 stycznia 2018

handball and football players (Mair et al., 2017). Systemic diseases like renal osteodystrophy and secondary hyperparathyroidism, as well as, systemic or local steroid use are predisposing factors.

The distal triceps tendon consists of the triceps proper, the tendinous part that inserts on the olecranon, and the triceps expansions, which insert to the posterior crest of the ulna medially, to the fascia of the extensor carpi ulnaris and the anconeus laterally and to the antebrachial fascia distally. The tendon proper is further divided into a deep part, which consists of tendon fibres 
from the medial head, and a superficial part, with fibres from the lateral and long heads of the triceps (Madsen et al., 2017). There is no established classification for triceps tendon ruptures. They can be grossly divided in partial thickness tears, partial full thickness and complete tendon ruptures (Madsen et al., 2017). Complete tears account for about $25-50 \%$ of all distal triceps tendon tears (van Riet et al., 2003; Madsen et al., 2017; Mair et al., 2017).

\section{Aim}

It was the aim of this paper to present acute distal triceps tendon ruptures and to describe our preferred surgical treatment technique in detail.

\section{Material and methods}

Diagnosis

The distal triceps tendon usually ruptures due to a forced eccentric loading, such as from a fall. Acute pain, ecchymosis, swelling, pain on palpation, a palpable defect and weakness are common clinical findings. The diagnosis may still be missed as loss of extension strength varies with the size of the rupture and may range from inability to extend the elbow against gravity (complete tendon proper rupture with involvement of the lateral extension) to weakness in end range extension (complete tendon proper rupture but intact expansions) to isolated weakness for extension beyond $90^{\circ}$ of flexion (partial-thickness tear of the deep insertion of the tendon proper) (Madsen et al., 2017). It is important to test extension strength bilaterally with the elbow in extension and in full flexion. Palpation does not always reveal gapping as a partial tear may be deep in the tendon proper. Even in full thickness tears it is sometimes difficult to palpate a gap at the insertion. The patient may not allow deep palpation due to pain or the gap may not be evident with the muscle relaxed. It is important to palpate the tendon in both the contracted and relaxed states.
Radiographic examinations usually include standard AP and lateral radiographs to exclude an olecranon avulsion or displaced traction spur (fleck sign) or concomitant fractures. Ultrasound may be very helpful but is dependent on the experience of the sonographer. MRI may not be necessary in a clinically clear complete tendon rupture but it may be needed to diagnose an obscure small total- or partial-thickness tear (Madsen et al., 2017).

\section{Treatment}

The treatment of triceps ruptures depends on the type of rupture and on the patient's demands and health status. Surgery is usually considered for complete tendon ruptures and for large incomplete ruptures (> 50\% of tendon proper involvement on MRI). In lower grade ruptures $(<50 \%$ of tendon proper involvement) and in partial-thickness tears, the treatment is controversial and dependent on the functional deficit and patient's activity level. When an extension lag is present, surgery is generally advised. Surgery is also preferred for high-level athletes with partial thickness tears (Anzel et al., 1959; van Riet et al., 2003; Blackmore et al., 2006; Yeh et al., 2010; Madsen et al., 2017; Mair et al., 2017).

The non-surgical treatment usually consists of splint immobilisation in $30^{\circ}$ of flexion for 3 to 6 weeks (Yeh et al., 2010). A brace may be used to allow early return to sport (Mair et al., 2017).

\section{Surgical technique}

Surgery is performed under general anaesthesia with the patient in a prone or lateral decubitus position (Figure 1A). We use a tourniquet in acute cases, as tendon retraction is usually not a problem. A straight posterior incision is made, centred over the olecranon tip and thick subcutaneous flaps are developed (Figure 1B). The ulnar nerve is identified and protected but usually not formally released. The tendon is debrided to healthy tissue and mobilized until it 
can be reduced to the olecranon in extension (Figure 2A and 2B). Two crossing bone tunnels are drilled with a $2.5 \mathrm{~mm}$ drill from medial to lateral to protect the ulnar nerve (Figure 3A). A suture anchor is drilled centrally into the insertion at the tip of the olecranon. A non-absorbable No. 2 suture is shuttled through the bone tunnels from proximal to distal (Figure 3B). The tendon proper is reduced to the proximal ulna. At this point, it may be necessary to fully extend the elbow to reduce the tendon (Figure 4). Sutures from the anchor are used to fix the tendon in the reduced position. To avoid irritation, all knots are buried in the proximal tendon tissue. Bone tunnel sutures are used to reinforce the medial and the lateral expansion to the tendon proper. These are knotted distally and knots are buried in the forearm musculature (Figure 5A).

At this point, it is crucial that the repair is tested. The elbow is gently flexed to evaluate

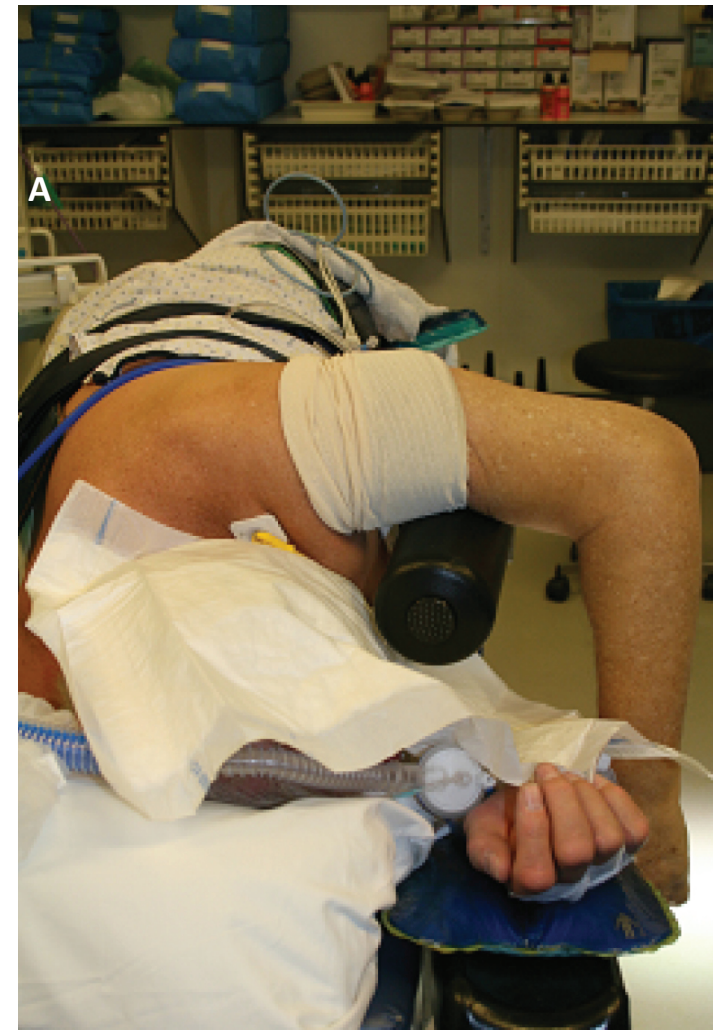

any gapping at the insertion site. If gapping occurs, the repair can be fortified with further sutures (Figure 5B and 5C).

\section{Rehabilitation}

In acute repairs, the elbow usually does not need to be immobilized and may be used without movement restrictions. A splint may be used for the first postoperative days for pain relief and protection from unintended movements. In subacute cases or after extensive debridement, the tendon proper can often only be reduced to the olecranon in full extension. In these patients, an extension plaster splint may be used, followed by a brace that allows progressive flexion. In the first 2 weeks, flexion is allowed to $30^{\circ}$, in the second two weeks to $60^{\circ}$ and in the last two weeks to $90^{\circ}$. After six weeks, gentle strengthening exercises may be started and unrestricted loading is allowed after three months.

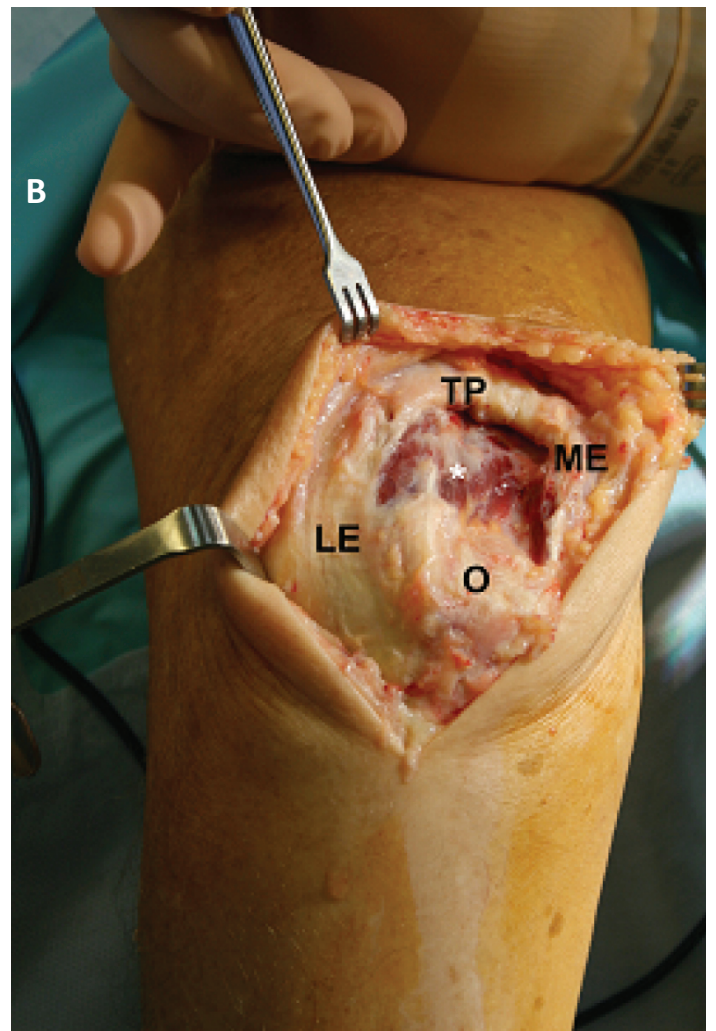

Figure 1. (A) Intraoperative photograph with the patient in lateral decubitus position. Note the posterior swelling at the site of the rupture (Courtesy of MoRe Foundation). (B) Complete rupture of the superficial part of the tendon proper (TP), the muscular medial head insertion $\left({ }^{*}\right)$ is still intact (LE: lateral expansion; ME: medial expansion) (Courtesy of MoRe Foundation). 

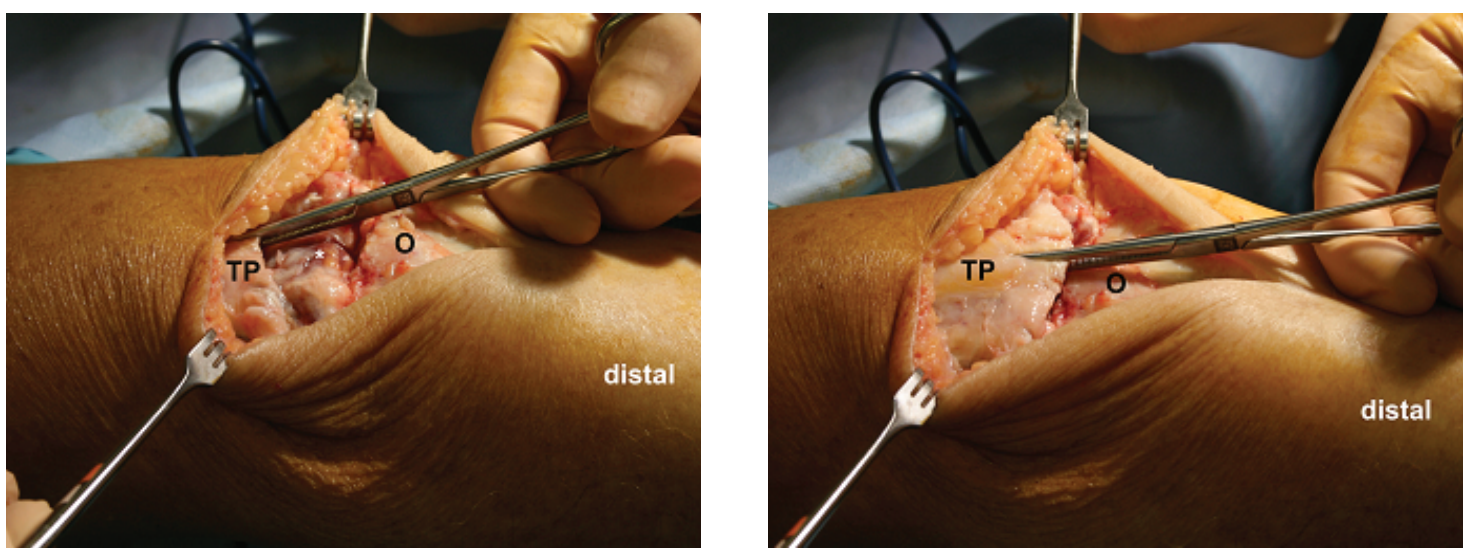

Figure 2. (A) The tendon proper is grasped and reduced to the olecranon with the elbow held in extension. (B) (TP: triceps proper; O: olecranon; * medial head of triceps) (Courtesy of MoRe Foundation).
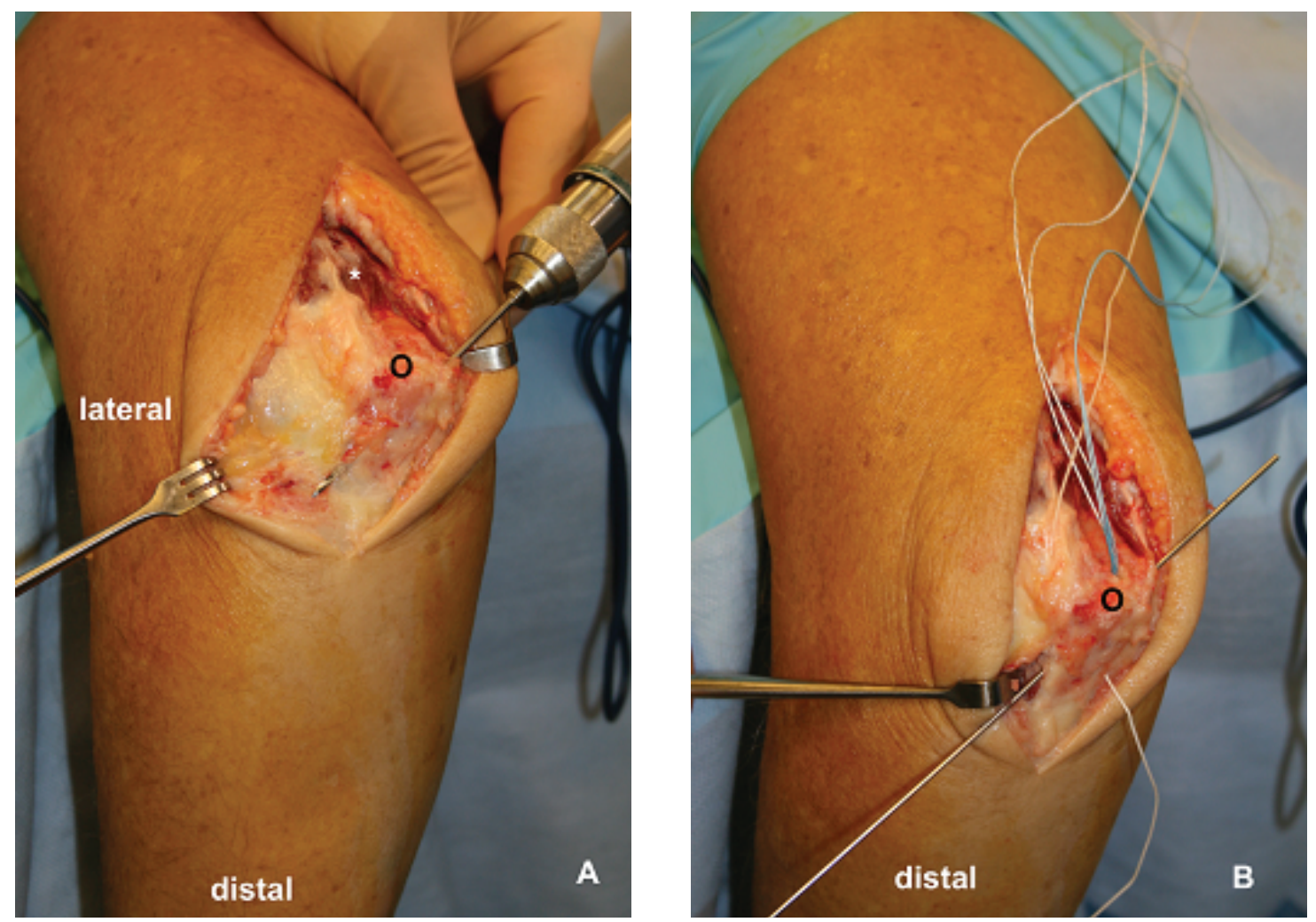

Figure 3. (A) Drilling of the bone tunnels must be performed from medial to lateral to protect the ulnar nerve. (B) After both bone tunnels are drilled two separate sutures may be shuttled trough the tunnels, and a central bone anchor is placed in the olecranon. (O: olecranon; ${ }^{*}$ medial head of triceps) (Courtesy of MoRe Foundation).

\section{Results}

Functional outcome and complications The results following primary repair of acute triceps ruptures are very good. A minor decrease in range of motion has been published with a mean extension deficit of $8^{\circ}$ and flexion to $138^{\circ}$, with isokinetic strength fully recovering after one year of follow-up (van Riet et al., 2003). In high level athletes, return to play rate is high after surgical repair of complete tendon ruptures (Mair et al., 2017).

Reruptures are rare and usually result from another traumatic incident. If the rerupture is diagnosed and treated acutely, it may be addressed with another repair with the same positive postoperative results (van Riet et al., 2003). Potential postoperative 

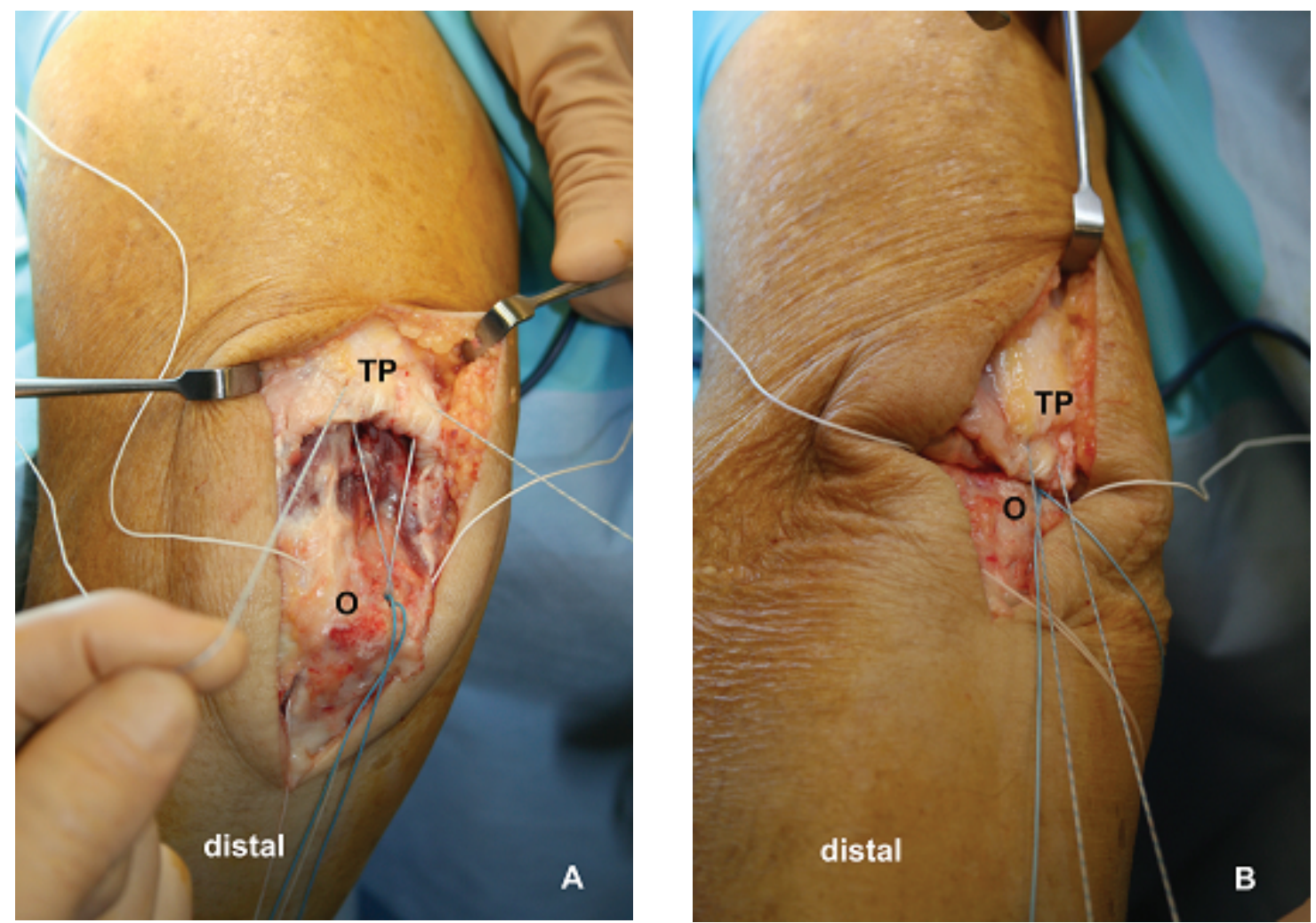

Figure 4. (A) The first strand of the bone anchor is sutured through the tendon proper (TP) and used to reduce the tendon (O). (B) The tendon proper is fixed in this position. (* medial head of triceps) (Courtesy of MoRe Foundation).
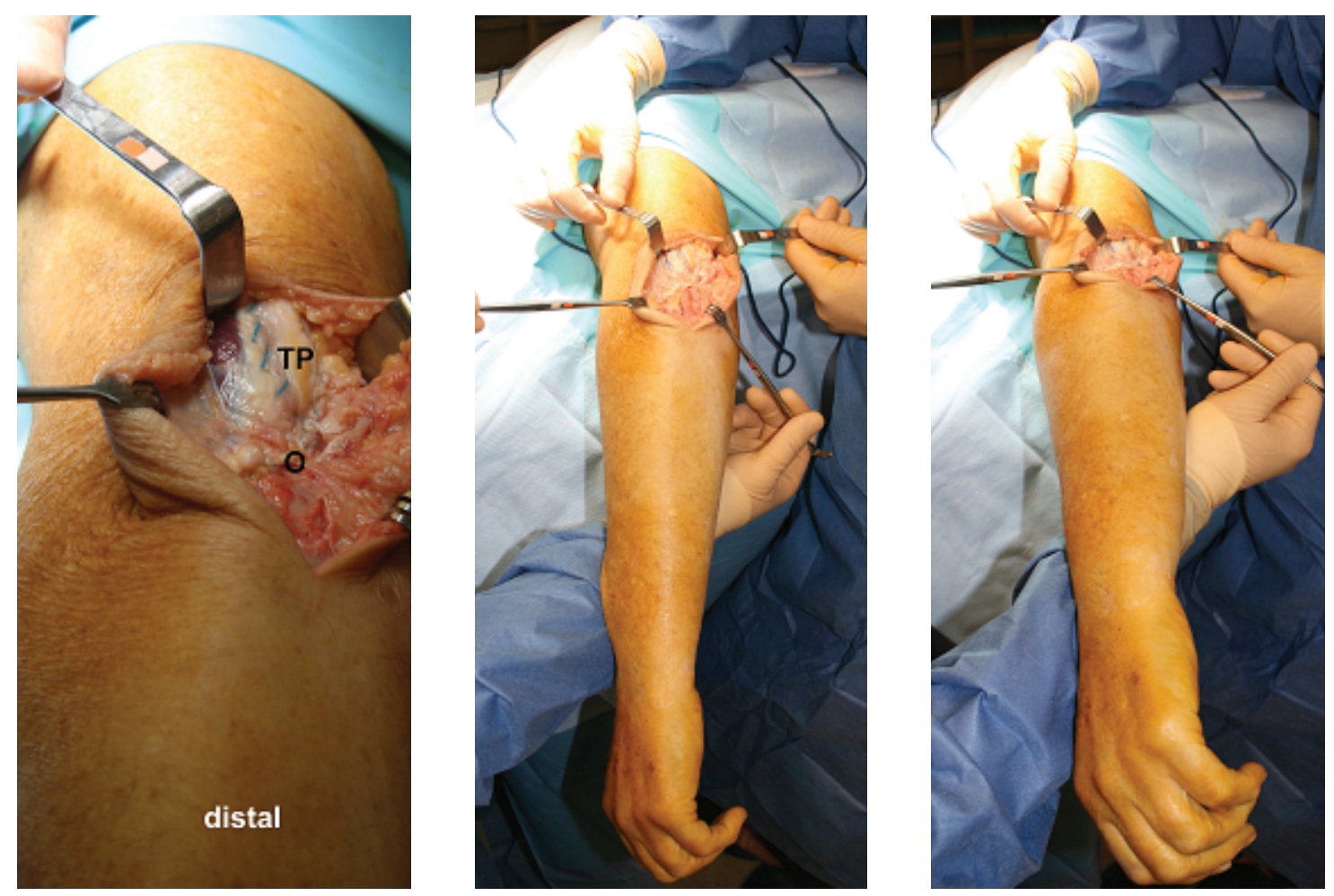

Figure 5. (A) Intraoperative photograph showing fixation of the distal triceps tendon (Tendon proper: TP, Olecranon: O) (Courtesy of MoRe Foundation). (B) Testing the repair by gently flexing the elbow (Courtesy of MoRe Foundation). (C) The repair is stable to approximately $45^{\circ}$ of flexion. The patient will be instructed not to flex past $45^{\circ}$ of extension for the first two weeks after which gentle mobilisation is permitted (Courtesy of MoRe Foundation). 
complications include flexion contracture ranging from 5 to $20^{\circ}$, olecranon bursitis and ulnar nerve neuritis (Yeh et al., 2010).

\section{Discussion and conclusions}

Acute triceps tendon ruptures are uncommon injuries. Risk factors are chronic overuse (e.g. weight lifting), direct trauma with eccentric loading, steroid use, previous surgery and systemic factors. The clinical diagnosis may be difficult in partial thickness or incomplete tears. Ultrasound and MRI may be used to confirm the diagnosis. The indication for surgery depends on the size of the tear, functional impairment and patient's demands. Surgical repair offers predictable good functional results with a low risk for complications. 
REFERENCES

Anzel S, Covey K, Weiner A, Lipscomb P. (1959) 'Disruption of muscles and tendons; an analysis of 1, 014 cases.' Surgery. 45:406-414. Blackmore SM, Jander RM, Culp RW. (2006) 'Management of distal biceps and triceps ruptures.' J Hand Ther., 19:154-168.

Madsen M, Marx RG, Millett PJ, Rodeo SA, Sperling JW, Warren RF. (2017) 'Surgical Anatomy of the Triceps Brachii Tendon.' Am J Sports Med., 34:1839-1843.

Mair SD, Isbell WM, Gill TJ, Schlegel TF, Hawkins RJ. (2017) 'Triceps Tendon Ruptures in Professional Football Players.' Am J Sports Med., 32:431-434.

van Riet RP, Morrey BF, Ho E, O'Driscoll SW. (2003)'Surgical treatment of distal triceps ruptures.' J Bone Joint Surg Am., 85-A: 1961-1967.

Yeh PC, Dodds SD, Smart LR, Mazzocca AD, Sethi PM. (2010) 'Distal triceps rupture.' J Am Acad Orthop Surg., 18:31-40.

Authors reported no source of funding. Authors declared no conflict of interest.

Author responsible for correspondence: Roger P. van Riet AZ Monica Hospital and Monica Orthopaedic Research (MoRe) Foundation, Stevenslei 20, 2100 Antwerp, Belgium drrogervanriet@azmonica.be
Autorzy nie zgłosili źródła finansowania. Autorzy nie deklarowali konfliktu interesów.

Autor odpowiedzialny za korespondencję: Roger P. van Riet AZ Monica Hospital and Monica Orthopaedic Research (MoRe) Foundation, Stevenslei 20, 2100 Antwerp, Belgia drrogervanriet@azmonica.be 